www.jmscr.igmpublication.org

Impact Factor 3.79

ISSN (e)-2347-176x

crossref DOI: http://dx.doi.org/10.18535/jmscr/v3i8.23

Journal Of Medical Science And Clinical Research

IGM Publication

An Official Publication of IGM Publication

\title{
Awareness of HIV/AIDS among Rural Population in Bathinda District of Punjab
}

\author{
Author \\ Kamaljit Kaur \\ Research Scholar \\ Desh Bhagat University, Mandi Gobindgarh (Punjab, India)
}

\begin{abstract}
A study was conducted to assess the awareness of HIVIAIDS among 300 rural peoples in the Bathinda district of Punjab. It was found that about 40\% of rural people were aware about the transmission of HIV/AIDS through sexual, blood and only 20\% persons know about the mother to child transmission of HIV/AIDS. 60\% population don't know what is the difference between HIV/AIDS. All are saying if they have virus of HIV in body it is AIDS.
\end{abstract}

Keywords: - Awareness, HIV, AIDS, Sexual, Transmission, virus, Rural.

\section{Introduction}

HIV/AIDS the modern day epidemic. It is, the acronym of acquired immune deficiency syndrome, it is the end stage disease in human body called immune deficiency virus. Due to HIV infection the person has no ability to fight off any infection. Consequently destruction of the patient's immune system. HIV is transmission through sex, and direct contact with infected blood from mother to child, breast feeding, semen and possibly pre- seminal fluid, vaginal secretions. HIV/AIDS is one of the challenges the world is facing today. National Aids Control organization (NACO) estimated that till April 20152.08 million people live with HIV infection. As per estimated by NACO, Punjab will have approximately 45948 cases of HIV infection and Bathinda district will have 1699 cases of HIV infection in the near future. The most common route of transmission of HIV/ AIDS is heterosexual. There are many factors which promote the rapid spread of HIV/AIDS. However, these factors may vary in the different parts of the world. For instance, demographic, socio-cultural as well as economic factors play important role in allowing rapid spread of the virus among people triggering an epidemic. There are numerous congregations culpable for spreading this incurable infection. The top three high risk groups for contracting HIV/AIDS are truck drivers, drug addicts and unprotected heterosexual partners. Besides, injecting drug users are prone to come under the infection. The HIV virus is transmitted primarily through the exchange of blood using needles, syringes and infected cotton swabs.

In Punjab the incidence of HIV is as high as $21.2 \%$ in IDU, alone there is lack of knowledge about safer needle use technique as well as alternatives of needle sharing for example, available suppliers of clean new needle syringes 
with the result it contributes to the rise of HIV/AIDS. The patient of HIV should understand the progression of the disease i.e., the initial infection, through window period, symptomatic infections, under the grip of AIDS. The patient is not aware of this disease and is being confused with related symptoms even he approached the doctor. The person may linger on with these symptoms that may continue maximum for the period 10 or more years depending on the immunity or to fight against this disease. In other words several years of HIV infection or mild symptoms then later may turned into severe infections lead to AIDS. Treatment appears to extend the life span and improve the quality of life of the patients. Although estimating survival after an AIDS diagnosis is inexact.

The AIDS and HIV virus is a very dangerous disease that sees no race, no color, no gender, no economic background and not even a specific age group. In spite of AIDS prevention drives, the use of preventive methods is still an exception and sexually transmitted disease continues to be a major problem in urban as well as rural areas. According to estimate data 3 to 4 percent of the rural population is suffering from such disease in the country. It is quite evident from the various reports that prevention efforts so far have been in effective in slowing the rate of infection. Prevention is better than treatment to cure' is the best - suited strategy in case of INDIA and other developing countries with huge population. And this is being stresses by all the concerned nations to combat this evil. The awareness would certainly grow with time but it should be attempted to sensitise generations with the help of print and electronic media. When AIDS first emerged, no one could have predicted how the epidemic would spread across the world and how many millions of lives it would damage. There was no real idea what it may cause and consequently, no real idea how to protect against it. In the latter's it was that AIDS is caused by the virus HIV, and it can devastate individual, families, communities and whole society the other continents. We have seen the epidemic knock decades ago and revealed that widen the gulf between rich and poor nations and already - stigmatized groups closer to the margins of society. We are living in global society, and HIV has become the first truly international epidemic, easily crossing oceans and international borders. In order to resist this deadly taint the right approaches, applied quickly enough with courage and resolve, can result in lower national HIV infection rates and less suffering for those affected by this epidemic. Globally, we have learned that if a country acts promptly, a national HIV crisis can be averted. It has also been noted that a country with a very high HIV prevalence rate will often see this rate eventually stabilize, and even decline if the quick actions are taken in this direction it requires awareness among the people in the beginning to change such risky behaviour pattern. They should learn lesson from the people who have been killed by AIDS. Fear is the worst and last way of changing people's behaviour and by the time if this happens it may be usual late to save a huge number of that country's population. In another study by Sarkar, Danabalan and Kumar (2007) regarding knowledge \& attitude about HIV/AIDS among married women about AIDS aged 15- 50 years in rural area of Pondicherry, the sources of acquiring knowledge were television $(81.98 \%)$ radio $(42.79 \%)$ and Newspaper $(15.76 \%)$.

\section{Objectives of the study:-}

- To assess the awareness of HIV/AIDS among rural peoples in the Bathinda district of Punjab.

- To study the knowledge of HIV/AIDS and attitudes towards the infection.

\section{Area of study:}

The study was conducted in 10 villages of Bathinda district (Punjab, India). These ten villages namely Dhunike, Bandi, guruke, faridkotkotli, kotlisabo, mahhalan, chackattarsingh wala, bajak, jangirana, bambiha.

\section{Research methodology: -}

The present study was conducted on males and females of age group 18-30 years. Interview 


\section{JMSCR Vol.||03||Issue ||08||Page 7040-7044||August}

schedule was prepared and final interviews were conducted after a pilot study. All confusions were cleared and required changes were made before actual interviews were conducted. Initially the help of village sarpanch, medical professionals, aganwari workers and other elders of the villages.

\section{Materials and methods}

The rural peoples of the Bathinda district of Punjab 10 villages selected for the study. Out of this 10 villages 200 male and 100 females were selected randomly for this study. From these households every $10^{\text {th }}$ house was included in this study. The questionnaire and interview technique employed for sampling. In the selected houses, all residents 10 years and above were included in this study.

\section{Inclusion criteria:}

All individuals above 18 years of age staying in the above mentioned area.

\section{Exclusion criteria:}

Individuals who were staying alone, suffering from major mental or physical disorders, mental retardation and stayed in villages for less than 1 year were excluding from this study.

\section{Table1}

\section{Demo graphic profile of respondents}

\begin{tabular}{|c|c|c|c|c|}
\hline Parameters & Male & Female & Percentage male & Percentage female \\
\hline \multicolumn{5}{|l|}{ Age } \\
\hline $18-22$ & 80 & 35 & $40 \%$ & $35 \%$ \\
\hline $23-26$ & 70 & 50 & $35 \%$ & $50 \%$ \\
\hline $27-30$ & 50 & 15 & $25 \%$ & $15 \%$ \\
\hline \multicolumn{5}{|c|}{ Family background } \\
\hline Rural & 200 & 100 & $100 \%$ & $100 \%$ \\
\hline Type of family & & & Percentage male & Percentage female \\
\hline
\end{tabular}

\begin{tabular}{|l|c|c|c|c|}
\hline Nuclear & 150 & 80 & $75 \%$ & $80 \%$ \\
\hline Joint & 50 & 20 & $25 \%$ & $20 \%$ \\
\hline $\begin{array}{l}\text { Education } \\
\text { qualification }\end{array}$ & & & & \\
\hline Non-literate & 50 & 22 & $25 \%$ & $22 \%$ \\
\hline Under matric & 60 & 45 & $30 \%$ & $45 \%$ \\
\hline $10+2$ & 40 & 25 & $20 \%$ & $25 \%$ \\
\hline Graduation & 30 & 5 & $15 \%$ & $5 \%$ \\
\hline Post- graduate & 20 & 3 & $10 \%$ & $3 \%$ \\
\hline
\end{tabular}


Table 2

Showing correct response about knowledge regarding HIV/AIDS

\begin{tabular}{|l|c|c|c|c|}
\hline General information about HIV/AIDS & MALE & FEMALE & $\begin{array}{c}\text { Percentage } \\
\text { male }\end{array}$ & $\begin{array}{c}\text { Percentage } \\
\text { female }\end{array}$ \\
\hline Communicable disease & 90 & 31 & $45 \%$ & $31 \%$ \\
\hline Damage immune system & 50 & 12 & $25 \%$ & $12 \%$ \\
\hline Incurable & 10 & 23 & $5 \%$ & $23 \%$ \\
\hline Not clarity & 50 & 42 & $25 \%$ & $42 \%$ \\
\hline ABBREVATIONS & & & & \\
\hline HIV & 23 & 10 & $11.5 \%$ & $10 \%$ \\
\hline AIDS & 107 & 78 & $53.5 \%$ & $78 \%$ \\
\hline STI & 5 & 2 & $2.5 \%$ & $2 \%$ \\
\hline ICTC & 60 & 10 & $30 \%$ & $10 \%$ \\
\hline METHODS OF PREVENTION & & & & \\
\hline Safe sex & 50 & 20 & $25 \%$ & $20 \%$ \\
\hline Safe blood transfusion & 10 & 3 & $5 \%$ & $3 \%$ \\
\hline Unused needles and syrings & 140 & 60 & $70 \%$ & $60 \%$ \\
\hline Pre natal screening for pregnant women & 0 & 17 & $0 \%$ & $17 \%$ \\
\hline Misconceptions about modes of transmission & & & & \\
\hline Transmission through mosquito bite & 10 & 12 & $5 \%$ & $12 \%$ \\
\hline Transmission through touching & 90 & 60 & $45 \%$ & $60 \%$ \\
\hline Transmission through sharing food & 50 & 10 & $25 \%$ & $10 \%$ \\
\hline Transmission through interaction & 50 & 18 & $25 \%$ & $18 \%$ \\
\hline Sources of information & & & & \\
\hline T.V. & 103 & 41 & $51.5 \%$ & $41 \%$ \\
\hline RADIO & 24 & 9 & $12 \%$ & $9 \%$ \\
\hline NEWSPAPER & 35 & 20 & $17.5 \%$ & $20 \%$ \\
\hline ASHA WORKER/ANM/RMP & 10 & 22 & $5 \%$ & $22 \%$ \\
\hline MEDICAL POSTER & 30 & 2 & $15 \%$ & $2 \%$ \\
\hline BOOKS & 20 & 1 & $10 \%$ & $1 \%$ \\
\hline OTHERS(Like friends, relatives etc.) & & 5 & $15 \%$ & $5 \%$ \\
\hline
\end{tabular}

\section{Highlights of Findings}

1. Many women still lack basic information about AIDS.

2. Women in most disadvantageous positions culturally and economically much less likely to be aware of AIDS.

3. Education, household index, media habits positively associated with AIDS knowledge Interpersonal communication weak source of disseminating AIDS information.

4. Misconceptions about transmission of AIDS still widespread among general population especially in Bathinda district of Punjab.

\section{Discussions}

This study reveals that the rural population of bathinda district of Punjab have lack of awareness about HIV/AIDS. In our study, the rural peoples have source of information from T.V. $51 \%$ male and $41 \%$ females. There are many misconceptions about transmission of HIV/AIDS in people of this region. The major problem in this study arise was difference between HIV and AIDS. The present study depicts that the main reasons for its rapid growth are lack of education, lack of awareness among rural peoples of Bathinda district. Prevention and intervention strategies need to focus on Punjabi rural peoples whose self perception of HIV/AIDS rise may be low, but whose risk is inextricably linked to the behaviour of their spouse. 


\section{References}

1. Bhardwaj A, Gupta B, Ahluwalia S, et al. Women and AIDS: Awareness and attitude in a semi urban setting in Punjab. Indian journal of maternal and child health 2011; 13 (2); 1-11

2. Devi S, Singh V, et al. Knowledge on PPTCT programme among married women in an urban community of imphal west, Manipur. Journal of medical society. Jan-April (2013; 27 (4); 39-42.

3. Global summary of the AIDS epidemic 2011.

4. Singh A, khans, chaudhary V,et al .knowledge and awareness about HIV /AIDS women of reproductive age in a district of nor then India, national journal of community medicine . 2012: 3 (3) 417422.

5. UNAIDS Report of the AIDS epidemic 2013. 